\title{
EFFECT OF PRECEDING CROPS AND NITROGEN LEVELS ON YIELD OF SUNFLOWER AND MAIZE INTERCROPPING. Abou-Elela, A.M. And A.M. Sheha Crops Intensification Dept.Agric.Res.Center,Giza,Egypt.
}

\section{ABSTRACT}

Two field experiments were conducted during 2011and2012season at Gemmeza Research Station,El Gharbia Governorate,Egypt,to study the effect of two winter crops(pure stands of fodder beet and Lentil in addition to their mixed cropping) on two successive summer crops of sunflower and maize. The first experiment was initiated in 2010/2011 winter season and terminated in 2011 the summer season whereas; initiation and termination of the second experiment were winter and summer seasons of 2011/2012,respectively.

The experimental design was split-plots design with three replication, where the preceding winter crops (fodder beet, mixed fodder beet +lentil and lentil) comprised the main plots (Both sunflower (Sakha $53 \mathrm{cv}$.) and maize (Giza $310 \mathrm{Cv}$.) were sown following the two winter crops as a relay crop into pure fodder beet $\left(\mathrm{S}_{1}\right)$ and mixed fodder beet and lentil $\left(\mathrm{S}_{2}\right)$ after lentils removal in addition after lentils as a double crop $\left.\left(\mathrm{S}_{3}\right)\right)$ and three nitrogen levels $\left(\mathrm{N}_{1}=90, \mathrm{~N}_{2}=105\right.$ and $\mathrm{N}_{3}=120 \mathrm{~kg} \mathrm{~N} / \mathrm{feddan}$ ) were tried in a sub-plot. Each sub-plot was $24 \mathrm{~m}^{2}$ in area, consisting of 5 ridges (each, $4 \mathrm{~m}$ long and $1.2 \mathrm{~m}$ wide).

Results were summarized as follows;

1-All the traits of sunflower were significantly affected by preceding winter crops in both seasons, except,plant height and No. of leaves/plant in both seasons.

2-All characters of maize were significantly affected by preceding winter crops and nitrogen levels in both seasons,expect, ear leaf area in both seasons .

3-The interaction between preceding crops and nitrogen levels had insignificant effect on all traits of sunflower and maize in both seasons.

4-The highest values of Land equivalent ratio(LER)were 1.405 and 1.472 in the two seasons, respectively, with preceding crops.

5-The highest values ofArea time equivalent ratio(ATER) were ( 1.306 and 1.343) in the two seasons, respectively, with preceding crops.

6- The highest values of Relative crowding coefficient(RCC) were(6.76 and 7.79) in the two seasons, respectively, with preceding crops.

7-Aggressivity $(\mathrm{Ag})$ indicated that sunflower was the dominat crop ,whereas, maize was the dominated in both seasons.

8-The highest values of cereal units were observed by lentil for preceding crop.

9 -The highest gross return was obtained by lentil with(N3).

\section{INTRODUCTION}

Appropriate cropping pattern along with optimum mineral nutrition and choice of component crops for multiple cropping systems plays an important role in increasing crop productivity. Multiple cropping has been based on the degree of physical association of crops, rang in from no to partial to full or almost full association. Such type of land yield intensification describes cropping practices that achieve the total productivity of land -unit area through a farming year. The attainable yield obtained from crop intensification can result from growing crops in mixtures, sole crops in sequence or a combination of mixed and sole crops in sequence-land yield advantage would be full filled by multi crops forms, could be due to greater 


\section{Abou-Elela, A.M. And A.M. Sheha}

removal of growth resources, either must be externally supplied or utilized within the cropping system (Fauki and Trenbath, 1993). Advantages of legume-non legume intercropping have due to greater land use and efficiency (Francis, 1984) and improvement of soil fertility, through $\mathrm{N}$ fixation and excretion from the component legume (Khalil and Nawar, 2004). Abu Kresha et al., (1991) reported yield advantage of fodder beet and faba bean when the two crops were intercropped in alter rate ridges. However, Khalil et al., (1997) found that when fodder beet was intercropped with faba been on the same ridge, it was disadvantageous where LER was less than unity. The values of legume introduction into a sequential cropping system could be attributed to the contribution they may make to the following crops, e.g. soil supply with organic $\mathrm{N}$ and reduction of its reliance on chemical fertilizers (Khalil et al., 2004 and Nawar, 2004). Intensive crop sequence aim to save time enough for triple and quadruple sequential cropping system. Relay along with cultivation of short duration crops could attain the time saving and, inturn , the land yield intensification (Khalil et al., 2011).

Nitrogen is the most limiting essential nutrient for sunflower and maize production. It is the main driving force to produce large yields because nitrogen is vitally important and is required in large amounts. Efficient use of $\mathrm{N}$ in maize production requires the ability to adjust the quantity of nitrogen applied in relation to the variation in local soils. Standford (1966 and 1973) presented convincing evidence that reasonable estimates of internal $\mathrm{N}$ requirements can be used to estimate the $\mathrm{N}$ fertilizer needs for maximum crop production. However, Viet (1965), concluded that the total $\mathrm{N}$ requirement of a crop cannot be accurately predicted.

The present study was conducted to evaluate sunflower and maize potential yield and some other agronomic traits to different preceding crops, as well as, its response to different $\mathrm{N}$ fertilization le

\section{MATERIAIS AND METHODS}

Two field experiments were carried out El-Gemmiza, Agricultural Research Station, Agricultural Research Center, Egypt to investigate the effect of two winter crops (pure stands of fodder beet and Lentils in addition to their intercropping) on two successive summer crops of sunflower and maize. The first experiment was initiated in 2010/2011 winter season and terminated in 2011 the summer season whereas; initiation and termination of the second experiments were winter and summer seasons of 2011/2012 and 2012, respectively.

The experimental design was split-plots design with three replication, where the preceding winter crops were fodder beet and lentil stand and intercropping comprised the main plots ( sunflower (C.V. Sakha 53) and maize (C.V. Giza 310) were sown following the two winter crops as a relay crop into pure fodder beet $\left(S_{1}\right)$ and mixed fodder beet and lentil $\left(S_{2}\right)$ after lentils removal in addition after lentils as a double crop $\left(\mathrm{S}_{3}\right)$ ) and three nitrogen levels $\left(N_{1}=90, N_{2}=105\right.$ and $N_{3}=120 \mathrm{~kg} \mathrm{~N} / \mathrm{fed}$.) were tried in a subplot. Each sub-plot was $24 \mathrm{~m}^{2}$ in area, consisting of 5 beds (each, $4 \mathrm{~m}$ long and $1.2 \mathrm{~m}$ wide for beds). 
Fodder beet was sown on the two sides of beds in hills (one plant/hill) at interspacing of $25 \mathrm{~cm}$ ( 28000 plants/fed.) . lentil was drilled (at $50 \%$ of the recommended seeding rate) in three rows (Spaced at $25 \mathrm{~cm}$ apart) on the upper beds. Sunflower(solid and in intercropping)was grown in one ridge on the upper beds after lentil harvested with one plant/hill,25x60 cm between (14000 plants/fed.).Maize solid and in intercropping) was grown on the two sides of beds after fodder beet harvested with one plant in hill $35 \times 60 \mathrm{~cm}$ between hill(20000plants/fed.) . Berseem was sown after removal sunflower between maize on the upper beds. Planting and harvesting dates of crops(foder beet ,foder beet+lentil,,lentil ,maize,sunflower and fahl berseem) as shown in Table(1).

Table 1: Planting and harvesting dates of foder beet, foder beet+ lentil, lentil, maize, sunflower and f. berseem 2011 and 2012season.

\begin{tabular}{|l|c|c|c|c|}
\hline Crops & \multicolumn{2}{|c|}{ First season 2011 } & \multicolumn{2}{c|}{ Second season 2012 } \\
\hline & $\begin{array}{c}\text { Planting } \\
\text { date }\end{array}$ & $\begin{array}{c}\text { Harvesting } \\
\text { date }\end{array}$ & $\begin{array}{c}\text { Planting } \\
\text { date }\end{array}$ & $\begin{array}{c}\text { Harvesting } \\
\text { date }\end{array}$ \\
\hline Foder beet & $10 / 11 / 2010$ & $29 / 5 / 2011$ & $15 / 11 / 2011$ & $3 / 6 / 2012$ \\
\hline Foder beet+Lentil & $10 / 11 / 2010$ & $29 / 5 / 2011$ & $15 / 11 / 2011$ & $3 / 6 / 2012$ \\
\hline Lentil & $10 / 11 / 2010$ & $28 / 3 / 2011$ & $15 / 11 / 2011$ & $2 / 4 / 2012$ \\
\hline Maize & $5 / 6 / 2011$ & $25 / 9 / 2011$ & $10 / 6 / 2012$ & $2 / 102012$ \\
\hline Sunflower & $15 / 4 / 2011$ & $20 / 7 / 2011$ & $20 / 4 / 2012$ & $24 / 7 / 2012$ \\
\hline f.berseem & $20 / 8 / 2011$ & $20 / 10 / 2011$ & $22 / 8 / 2012$ & $25 / 10 / 2012$ \\
\hline
\end{tabular}

Table 2: Soil samples were taken and analyzed following the methods described and chemically analyzed according to Black(1965).

\begin{tabular}{|c|c|c|c|c|}
\hline \multirow[t]{2}{*}{ Mechanical } & \multicolumn{2}{|c|}{ First season } & \multicolumn{2}{|c|}{ Second season } \\
\hline & $0-30$ & $30-60$ & $0-30$ & $30-60$ \\
\hline Clay \% & 57.14 & 55.21 & 55.47 & 54.00 \\
\hline Silt \% & 22.29 & 21.94 & 23.68 & 22.80 \\
\hline Sand \% & 20.57 & 22.85 & 20.85 & 23.20 \\
\hline Texture & \multicolumn{4}{|c|}{ Clay } \\
\hline \multicolumn{5}{|l|}{ Chemical analysis: } \\
\hline Available N (ppm) & 22.9 & 21.8 & 24.0 & 22.0 \\
\hline Available $\mathrm{P}_{2} \mathrm{O}_{5}(\mathrm{ppm})$ & 9.0 & 8.5 & 11.0 & 10.0 \\
\hline Available $\mathrm{K}_{2} \mathrm{O}$ (ppm) & 550 & 535 & 500 & 480 \\
\hline Ec $\left(\mathrm{mmhos} / \mathrm{cm}^{3}\right)$ & 0.8 & 0.8 & 0.9 & 0.9 \\
\hline $\mathrm{pH}$ & 7.40 & 7.3 & 7.3 & 7.2 \\
\hline $\mathrm{CaCo}_{3} \%$ & 2.71 & 3.10 & 3.0 & 3.0 \\
\hline Organic matter \% & 1.0 & 1.1 & 1.2 & 1.2 \\
\hline Cations (meq/100 g.soil) & & & & \\
\hline $\mathrm{Na}^{+}$ & 0.36 & 0.37 & 0.37 & 0.37 \\
\hline $\mathrm{K}^{+}$ & 0.01 & 0.01 & 0.03 & 0.04 \\
\hline $\mathrm{Ca}^{++}$ & 0.25 & 0.27 & 0.24 & 0.24 \\
\hline $\mathrm{Mg}^{++}$ & 0.26 & 0.28 & 0.22 & 0.22 \\
\hline \multirow{4}{*}{$\begin{array}{l}\text { Anions (meq/100 g. soil) } \\
\mathrm{HCO}^{3} \\
\mathrm{Cl}^{-} \\
\mathrm{SO}_{4}\end{array}$} & & & & \\
\hline & 0.32 & 0.48 & 0.36 & 0.40 \\
\hline & 0.38 & 0.39 & 0.28 & 0.30 \\
\hline & 0.20 & 0.06 & 0.22 & 0.12 \\
\hline
\end{tabular}




\section{Abou-Elela, A.M. And A.M. Sheha}

\section{Field sampling and data collection:}

At harvest time, a sample of 10 plants was randomly collected from each plot to measure:

A-Maize yield and its components

1- Plant height $(\mathrm{cm})$

2- Ear leaf area.

B- Sunfolwer yield and its components

3- Ear grain weight $(g)$

4- 100- grain weight $(\mathrm{g})$.

1- Plant height $(\mathrm{cm})$.

2- No.of leaves/plant.

3- Head diameter $(\mathrm{cm})$.

5 -Grain yield $\mathrm{ardab} / \mathrm{fed}$ - $-($ ardab $=140 \mathrm{kgs})$

4- Head seed weight/plant(g)

5- 100-seed weight ( $\mathrm{g}$ )

6- Seed yield $\mathrm{kg} / \mathrm{fed}$

-The plants in two ridges from maize, where one ridge from sunflower, of each experimental unit were harvested, collected together,labeled,threshed and the seeds were separated.The grain yield to maize and seed yield to sunflower was recorded in $\mathrm{kg} \mathrm{m}^{2}$, and then converted into grain yield in ardab/fed.to maize and seed seed yield in $\mathrm{kg} / \mathrm{fed}$. To sunflower.

The competitive behavior of component crops in different sunflowermaize association was determined in terms of Land Equivalent Ratio, relative crowding coefficient, aggerssivity and competitive ratio which were determined by using the following formulae.

Competitive functions. The following abbreviations were used to calculate different competitive functions.

$\mathrm{Y}_{\mathrm{aa}}$ pure stand yield of crop "a".

$\mathrm{Y}_{\mathrm{ab}}$ intercrop yield of crop "a".

$\mathrm{Y}_{\mathrm{bb}}$ pure stand yield of crop "b".

$Y_{b a}$ intercrop yield of crop "b".

$Z_{a b}$ and $Z_{b a}$ are sown proportions of crop "a" and "b" in an intercropping system.

Land Equivalent Ratio (LER). The ratio of area need under sole cropping to that of intercropping at the same management level to produce an equivalent yield, according to Willey and Osiru(1972). It is calculated as follows:

LER $=\mathrm{Y}_{\mathrm{ab}} / \mathrm{Y}_{\mathrm{aa}}+\mathrm{Y}_{\mathrm{ba}} / \mathrm{Y}_{\mathrm{bb}}$

Relative crowding coefficient. Relative crowding coefficient was proposed by De-wit (1960), which was calculated by the following formula:

$\mathrm{K}=\left(\mathrm{K}_{\mathrm{a}} \times \mathrm{K}_{\mathrm{b}}\right)$

$\mathrm{K}_{\mathrm{a}}=\mathrm{Y}_{\mathrm{ab}} \times \mathrm{Z}_{\mathrm{ba}} /\left(\mathrm{Y}_{\mathrm{aa}}-\mathrm{Y}_{\mathrm{ab}}\right) \times \mathrm{Z}_{\mathrm{ab}}$

$K_{b}=Y_{b a} \times Z_{a b} /\left(Y_{b b}-Y_{b a}\right) \times Z_{b a}$

Where,

$\mathrm{K}_{\mathrm{a}}$ and $\mathrm{K}_{\mathrm{b}}=$ Relative crowding coefficient for the component crop "a and $\mathrm{b}$ ". All other abbreviations such as $\mathrm{Y}_{\mathrm{aa}}, \mathrm{Y}_{\mathrm{ab}}, \mathrm{Z}_{\mathrm{ab}}, \mathrm{Z}_{\mathrm{ba}}$, have been described above in this section.

Aggressivity : Aggressivity value was calculated by the formula proposed by McGilchrist (1965).

$$
A a b=\frac{Y a b}{\text { Yaax Zab }}-\frac{Y b a}{Y b b \times \text { Zba }}
$$


Where,

$A_{a b}=$ Aggressivity value for the component crop "a".

All other abbreviations have been described above in this section.

Area time equivalent ration(ATER):Determined according to Hiebsch and McColhum(1987):

ATER $=($ Rym $x$ tm $)+($ Rysxts $)$

Where,Rym,Rys are Relative yield of maize and sunflower, respectively i.e.,(Yield of intercrop/fed)/(Yield of sole/fed)Intercropping grain of maize/Sole grain yield of maize.tm,ts are duration(days)for maize and sunflower from sowing to harvesting, respectively .T is duration(days)of intercropping pattern.

Table 3: The average yield of preceding winter crops in both seasons.

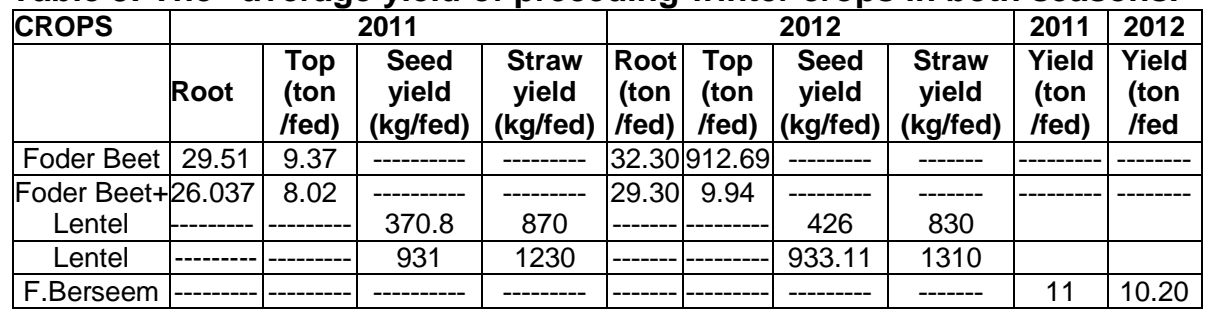

Cereal unit:

The yield of all crops were changed to units of cereal according by Brockaus(1962)for judicious comparison between $100 \mathrm{~kg}$ for each crops as follow:maize $=1$ unit,sunflower $=2$ units, foder beet $=0.25$ unit,lentil=1.20unit , fahl berseem $=0.14$ unit, straw yield for lentil $=0.25$ unit,maize $=0.15$ unit and staw yield Top for fodeer beet $=0.10$ unit.

Gross return

Gross return from each treatment was calculated in Egyptian pounds(LE)at praices of LE3415/ $t$ for (seed)sunflower , LE303/ ardab for maize andL.E.150/t for f.berseem.(Agricultural Statisties(2012),Economic Affairs Sector;Ministry ofAgriculture;Egypt;(in arabic).

Statistical analysis:

Data statistically analyzed as the technique analysis of variance (ANOVA) of split- plot design as mentioned by Gomez and Gomez (1984). Treatment means were compared using the Least Significant Difference (LSD at $5 \%$ ) test as outlined by Waller and Duncan (1969).

\section{RESULTS AND DISCUSSION}

Effect of winter preceding crops on yield and its components of maize .

Data in Table (4) indicated significant effect for preceding crops on plant height, ear grains weight, 100-grain weight and grain yield/fed over the two seasons.

Differences in plant height among the two preceding crops were significant and in significant greater for maize grown on lentil plots followed by mixed lentil and fodder beet, compared to maize grown on fodder beet 
plots. These might be attributed to the more availability of $\mathrm{N}$ and less $\mathrm{N}$ uptake as lentil in addition to lentil+fodder beet were the preceding crops. Consequently, maize did uptake greater $\mathrm{N}$ amount and had taller plants (Nawar,2004 and Khalil et al., 2011).

Table ( 4 ): Means of yield and its components for maize as affected by different preceding crops and $\mathrm{N}$ levels during 2011 and 2012 seasons.

\begin{tabular}{|l|c|c|c|c|c|c|c|c|c|c|}
\hline & \multicolumn{2}{|c|}{$\begin{array}{c}\text { plant } \\
\text { height(cm) }\end{array}$} & \multicolumn{2}{c|}{$\begin{array}{c}\text { ear leaf } \\
\text { area }\end{array}$} & \multicolumn{2}{c|}{$\begin{array}{c}\text { ear grain } \\
\text { weight(gm) }\end{array}$} & $\begin{array}{c}\text { 100-grain } \\
\text { weight(gm) }\end{array}$ & \multicolumn{2}{c|}{$\begin{array}{c}\text { grain } \\
\text { yield/fed(ardab) }\end{array}$} \\
\hline & $\mathbf{2 0 1 1}$ & $\mathbf{2 0 1 2}$ & $\mathbf{2 0 1 1}$ & $\mathbf{2 0 1 2}$ & $\mathbf{2 0 1 1}$ & $\mathbf{2 0 1 2}$ & $\mathbf{2 0 1 1}$ & $\mathbf{2 0 1 2}$ & $\mathbf{2 0 1 1}$ & $\mathbf{2 0 1 2}$ \\
\hline fodder beet(s1) & 283.09 & 283.16 & 577.05 & 669.33 & 146.34 & 135.05 & 32.71 & 34.71 & 14.46 & 15.71 \\
\hline Intercropping(s2) & 290.09 & 289.28 & 589.44 & 671.22 & 152.17 & 142.57 & 33.94 & 35.20 & 15.78 & 17.25 \\
\hline Lentil(s3) & 298.16 & 295.17 & 588.00 & 674.44 & 161.66 & 146.90 & 34.12 & 36.32 & 16.96 & 18.41 \\
\hline Solid & & & & & & & & & 22.35 & 24.65 \\
\hline LSD0.05 & 2.55 & 2.63 & NS & NS & 6.96 & 1.68 & 1.30 & 1.57 & 0.77 & 0.71 \\
\hline Nitrogen levels & & & & & & & & & & \\
\hline $90 \mathrm{~kg} \mathrm{~N}$ & 281.66 & 277.46 & 578.26 & 666.67 & 146.89 & 132.96 & 32.79 & 34.28 & 14.95 & 16.12 \\
\hline $105 \mathrm{~kg} \mathrm{~N}$ & 288.44 & 287.71 & 588.60 & 671.89 & 153.87 & 142.74 & 33.54 & 35.13 & 15.61 & 17.15 \\
\hline $120 \mathrm{Kg} \mathrm{N}$ & 301.23 & 302.43 & 587.62 & 676.44 & 159.41 & 148.81 & 34.43 & 36.82 & 16.64 & 18.10 \\
\hline LSD0.05 & 2.00 & 2.45 & $\mathrm{NS}$ & $\mathrm{NS}$ & 4.57 & 3.36 & 1.59 & 2.23 & 0.30 & 0.86 \\
\hline SxN & $\mathrm{NS}$ & $\mathrm{NS}$ & $\mathrm{NS}$ & $\mathrm{NS}$ & $\mathrm{NS}$ & $\mathrm{NS}$ & $\mathrm{NS}$ & $\mathrm{NS}$ & $\mathrm{NS}$ & $\mathrm{NS}$ \\
\hline
\end{tabular}

Ear grain weight for maize preceded by lentils was superior to that after lentils+ fodder beet compared to fodder beet. Doubt increased soil availability of $\mathrm{N}$ increased $\mathrm{N}$ uptake in $\left(\mathrm{S}_{2}\right)$ compared to $\left(\mathrm{S}_{1}\right)$, resulting $\mathrm{N}$ the increase of LAI photoaasimilates production and translocation into ears, Nawar, 2004 and Khalil et al., 2011 hence increased both number of fertile grains/ear and individual grain weight (Wallach, 1995).

Data on the effect of the preceding crop 100-grain weight showed that had a significant responses as influenced by the preceding winter crops. The 100-grain weight reached the maximum and minimum records when maize was grown following lentil and fodder beet, respectively. Improvement of physical and chemical properties, regarding soil $\mathrm{N}$ and organic matter content, might be associated with greater $\mathrm{N}$ uptake, followed by enhanced photoassimilates and translocation into ear grains, which produced the highest grain weight following lentil, compared to that after fodder beet.

Differences among preceding crops in grain yield/fed of maize were significant in both seasons. Lentil resulted in the highest significant grain yield, compared to fodder beet.

These results were attributed to the good residual effect of faba bean on soil fertility, greater $\mathrm{N}$ uptake and conversion into photoassimilates, resulting the increase of grain yield attributes and grain yield (Khalil et al., 2011).

Effect of $\mathbf{N}$ fertilization levels on yield and its components of maize.

Data in Tables ( 4 ) showed that, increasing $N$ levels had significant effect on all the studied characters, except for ear leaf area in both seasons. Increasing nitrogen levels up to $120 \mathrm{~kg} / \mathrm{fed}$. produced the highest values of all studied traits for maize in both seasons. These changes may positively 
affect LAI, photosynthesis and photoassimilates effect into grain and hence increasing grain yield (Khalil et al., 2004 and Fageria , 2007). Such effects resulted in $\mathrm{N}$ more efficient use which, in turn, was associated with early and moderate vegetative growth along with grain yield and its attributes (Fageria and Gheyi, 1999)

\section{Effect of preceding winter crops on yield and its components of sunflower:}

Data in Table (5) revealed that sunflower plants grown after lentils were significantly greater in head diameter than those grown after fodder beet, grown either alone or in association with lentils, during the two seasons.

Head diameter was 1.16 and $0.48 \mathrm{~cm}$ greater for sunflower grown after pure fodder beet and fodder beet intercropped with lentil in the first season and was 3.16 and $1.85 \mathrm{~cm}$ greater in the second season, respectively. Similar results were obtained by Khalil et al., (2004). These findings might be attributed to the beneficial effect of lentil on sunflower.

Variations in 100-seed weight between the two preceding crops were significant with similar trend in both seasons. Among these crops, lentil was superior to the other two preceding crops( fodder beet grown in association or pure stand.) Increases in such trait for sunflower grown after lentil, were 0.52 and $0.06 \mathrm{~g}$ in the first season and 0.85 and 0.76 in the second season compared to those after fodder beet and fodder beet withlentil, respectively. Theses results could be explained by lower $\mathrm{N}$ uptake by lentil and increased LAl coupled with more light use efficiency and assimilates production of sunflower (Gardner et al., 1985). Most of these assimilates were translocate into heads leading increase in a single seed weight (Sinclair and Horie, 1989). The data indicated that, sole cropped lentil produced higher seed yield/plant values of sunflower than those obtained from the sole cropping of fodder beet or from fodder beet-lentil intercropping plots. The longer the growth duration of sugar beet which was companied with a decline in soil $\mathrm{N}$ and organic matter the higher head seed weight (Khalil et al., 2011). Furthermore, nitrogen fixation with little $\mathrm{N}$ depletion by lentil also might be, responsible for a decline in photo assimilates production and portioning into heads.

Response of seed yield/fed to proceeding crops was significant and had the same course of change over the two seasons. Maximum productivity was obtained as sunflower followed lentil, however, when sunflower was planted after lentil + fodder beet and fodder beet, it ranked second and third regarding such trait, respectively. Increases in head diameter and a single seed weight might be responsible for increases in seed yield of sunflower. The beneficial effects of lentils on soil (Soil supply with $\mathrm{N}$ and organic matter in addition to lower $\mathrm{N}$ uptake) increased photoassimilates productivity and translocation to head, leading to increases in sunflower seed yield (Loomis and Connor, 1992). Khalil et al., (2011) attributed yield reduction of sunflower after fodder beet, as a result of greater $\mathrm{N}$ depletion and lower soil supply with organic matter by fodder beet.

In conclusion, data showed that when sunflower was preceded by lentils, rather than by lentil+fodder beet or fodder beet alone, increased head 
diameter and 100-seed weight, in addition to seed yield/plant which, in turn, led to increase in productivity seed yield/fed.

Effect of $\mathbf{N}$ fertilization levels on yield and its components of sunflower:

Data in Tables (5) showed that, increasing $\mathrm{N}$ levels had significant effect on all the studied characters, except for plant height in the first season and No of leaves/plant in both seasons. Increasing nitrogen levels up to 120 $\mathrm{kg} / \mathrm{fed}$. produced the highest values of all studied traits for sunflower in both seasons. The improvement in $\mathrm{N}$ uptake as a nutrient with the addition of $\mathrm{N}$ reported to be associated with increase in root system and physiological changes stimulated $\mathrm{N}$ application (Fageria and Baligar, 2005). Nitrogen application leads to increases in leaf generation and expansion, terms of leaf area index (LAl), that is associated with a sufficient light interception, $\mathrm{N}$ use efficiency and assimilates partitioning to grains resulting in increased grain yield (Sinclair and Horrie, 1989 and Khalil et al., 2004). The more the number of macronutrients applied, the greater the vegetative growth was in terms of increasing internodes number and length (Gardner et al., 1985). These changes may positively affect LAl, photosynthesis and photoassimilates effect into grain hence increasing grain yield (Khalil et al., 2004 and Fageria , 2007). Such effects resulted in $N$ more efficient use which, in turn, was associated with early and moderate vegetative growth along with grain yield and its attributes (Fageria and Gheyi, 1999)

\section{Effect of interaction between preceding crop and nitrogen levels on} sunflower:

Results presented in Table (4and5) indicate that no significant effects due to proceeding crops and nitrogen levels on sunflower for all studied traits in both seasons. On the table(5), maize showed not significant effects due to proceeding crops and nitrogen levels for all studied traits in both seasons.

Increasing nitrogen levels up to $120 \mathrm{~kg} \mathrm{~N} / \mathrm{fed}$. recorded the highest values for all studied traits for both crops (sunflower and maize) with lentil followed by the same levels of nitrogen with fodder beet+ lentil, while, the lowest values were recorded with fodder beet and the lowest level of nitrogen in both seasons.

Table ( 5 ): Means of yield and its components for sunflower as affected by different proceeding crops and $\mathrm{N}$ levels during 2011 and 2012 seasons

\begin{tabular}{|c|c|c|c|c|c|c|c|c|c|c|c|c|}
\hline & \multicolumn{2}{|c|}{$\begin{array}{c}\text { plant } \\
\text { height }(\mathrm{cm})\end{array}$} & \multicolumn{2}{|c|}{$\begin{array}{c}\text { No.of } \\
\text { leaves/plan }\end{array}$} & \multicolumn{2}{|c|}{$\begin{array}{c}\text { head } \\
\text { diameter(cm) }\end{array}$} & \multicolumn{2}{|c|}{$\begin{array}{c}100 \text {-seed } \\
\text { weight(gm) }\end{array}$} & \multicolumn{2}{|c|}{\begin{tabular}{|c|} 
seed \\
yield/p(gm)
\end{tabular}} & \multicolumn{2}{|c|}{$\begin{array}{c}\text { seed } \\
\text { yield/fed(kg) }\end{array}$} \\
\hline & 2011 & 2012 & 2011 & 2012 & 2011 & 2012 & 2011 & 2012 & 2011 & 2012 & 2011 & 2012 \\
\hline fodder beet(s1) & 140.81 & 142.81 & 21.29 & 23.10 & 14.76 & 16.90 & 5.30 & 5.39 & 41.47 & 40.21 & 634.71 & 693.81 \\
\hline Intercropping(s2 & 141.17 & 143.03 & 21.69 & 23.37 & 15.44 & 18.21 & 5.76 & 5.48 & 44.24 & 43.64 & 659.52 & 733.91 \\
\hline Lentil & 141.51 & & 21.68 & 23.20 & 15.92 & 20.06 & 5.82 & 6.24 & 46.36 & 46.11 & 683.71 & 799.64 \\
\hline Solid & & & & & & & & & & & 1015.17 & 1065.67 \\
\hline LSD0.05 & NS & NS & NS & NS & 29 & 1.61 & NS & 49 & .68 & 1.97 & 31.75 & 32.88 \\
\hline Nitr & & & & & & & & & & & & \\
\hline $90 \mathrm{~kg} \mathrm{~N}$ & 141.07 & 142.60 & 21.47 & 22.93 & 14.66 & 17.10 & 5.17 & 4.92 & 38.59 & 38.19 & 641.79 & 689.19 \\
\hline $105 \mathrm{~kg} \mathrm{~N}$ & 140.99 & 142.76 & 21.52 & 23.27 & 15.47 & 18.34 & 5.68 & 5.46 & 44.03 & 43.03 & 664.30 & 751.32 \\
\hline $120 \mathrm{Kg} \mathrm{N}$ & 141.43 & 143.39 & 21.67 & 23.47 & 16.00 & 19.72 & 6.03 & 6.73 & 49.44 & 48.74 & 671.86 & 786.86 \\
\hline LSDC & NS & NS & 0.86 & NS & NS & 0.37 & \begin{tabular}{|l|}
0.89 \\
\end{tabular} & 0.64 & 0.41 & 0.82 & 14.24 & 18.75 \\
\hline SxN & NS & NS & NS & NS & NS & NS & NS & NS & NS & NS & NS & NS \\
\hline
\end{tabular}




\section{Land equvalent ration(LER):}

Data in Table(6) revealed that increased land equivalent ration(LER)in all tretments in both seasons. The highest values were recorded with lentil as preceding crops(1.431and1.496) and the highest level of nitrogen (1.405 and1.472), in the first and second seasons, respectively, while,the lowest values were recorded with fodder beet(1.270 and1.288) and the lowest level of nitrogen(1.300 and1.299)respectively, with first and second seasons.

Table (6): Land equivalent ration and Area-Time equivalent ration from yields as affected by intercropping maize and sunflower 2011 and2012 season.

\begin{tabular}{|l|c|c|c|c|c|c|c|c|}
\hline $\begin{array}{l}\text { Treat } \\
\text { m-ents }\end{array}$ & \multicolumn{2}{|c|}{$\mathbf{2 0 1 1}$ season } & & $\begin{array}{c}\mathbf{2 0 1 2} \\
\text { season }\end{array}$ & & & \multicolumn{2}{|c|}{ ATER } \\
\hline & $\begin{array}{l}\text { Maize } \\
\text { (LER) }\end{array}$ & $\begin{array}{c}\text { Sunflow } \\
\text { er(LER) }\end{array}$ & $\begin{array}{c}\text { Total } \\
\text { (LER) }\end{array}$ & $\begin{array}{c}\text { Maize } \\
\text { (LER) }\end{array}$ & $\begin{array}{c}\text { Sunflo } \\
\text { wer } \\
\text { (LER) }\end{array}$ & $\begin{array}{c}\text { Total } \\
\text { (LER) }\end{array}$ & $\begin{array}{c}\mathbf{2 0 1 1} \\
\text { season }\end{array}$ & $\begin{array}{c}\mathbf{2 0 1 2} \\
\text { season }\end{array}$ \\
\hline S1 & 0.646 & 0.625 & 1.270 & 0.637 & 0.651 & 1.288 & 1.178 & 1.175 \\
\hline S2 & 0.706 & 0.649 & 1.355 & 0.699 & 0.688 & 1.387 & 1.258 & 1.268 \\
\hline S3 & 0.758 & 0.673 & 1.431 & 0.746 & 0.750 & 1.496 & 1.331 & 1.366 \\
\hline N1 & 0.668 & 0.632 & 1.300 & 0.653 & 0.646 & 1.299 & 1.179 & 1.187 \\
\hline N2 & 0.698 & 0.654 & 1.352 & 0.695 & 0.705 & 1.400 & 1.254 & 1.277 \\
\hline N3 & 0.744 & 0.661 & 1.405 & 0.738 & 0.733 & 1.472 & 1.306 & 1.343 \\
\hline
\end{tabular}

\section{Area time equivalent ratio(ATER):}

As LER does not take into account the time for which land is occupied by the component crops of intercropping system, area time equivalent ratio (ATER)was also calculated .The ATER provides a more realistic comparison of the yield advantage of intercropping over that of the sole cropping that the LER as it considers variation in time taken by the component crops of different intercropping systems. The ATER values shon in Table(6). The highest ATER was recorded for sunflower + maize after lentil( 1.366 ) followed by sunflower + maize after fodder beet+lentil(1.268)and sunflower+maize after fodder beet( 1.178), respectively. While the lowest values were(1.179)with $\mathrm{N} 1$ and the highest values were(1.343)with N3.

\section{Relative crowding coefficient(RCC).}

The best results were achieved by intercropping sunflower with maize after lentil and the highest values on nitrogen fertilizer in both seasons( Table 7). The highest values of (RCC) were (6.3 and 5.37) in the first and second seasons, respectively. On the other hand, the lowest values of (RCC)were(3.05 and4.64) in the two seasons, respectively, obtained from intercropping sunflower with maize after fodder beet in both season. While the lowest values was observed with $\mathrm{N} 1(3.060$ and3.459) in first and second seasons, respectively The highest values of( RCC) were(6.7627.798)in the first and second seasons, respectively with(N3) .

Aggressivety (A):

Data presented in (Table 7) revealed that aggressivety was affected by intercropping sunflower with maize and nitrogen fertilization in both seasons. Aggressivety values of sunflower were positive (dominant crop ,whereas, aggressivety values for maize was negative(dominated crop. 
Table 7: Competitive relationships calculated from yields as affected by intercropping maize with sunflower

\begin{tabular}{|c|c|c|c|c|c|c|c|c|c|c|}
\hline & \multicolumn{2}{|c|}{ Ka(maize) } & \multicolumn{2}{c|}{ Kb(sunflower) } & \multicolumn{2}{c|}{ RCC(k) } & \multicolumn{2}{c|}{ Aab(maize) } & \multicolumn{2}{c|}{ Aba(sunflower) } \\
\hline & $\mathbf{2 0 1 1}$ & $\mathbf{2 0 1 2}$ & $\mathbf{2 0 1 1}$ & $\mathbf{2 0 1 2}$ & $\mathbf{2 0 1 1}$ & $\mathbf{2 0 1 2}$ & $\mathbf{2 0 1 1}$ & $\mathbf{2 0 1 2}$ & $\mathbf{2 0 1 1}$ & $\mathbf{2 0 1 2}$ \\
\hline s1 & 0.90 & 0.67 & 3.39 & 3.78 & 3.05 & 4.64 & -0.93 & -1.02 & 0.93 & 1.02 \\
\hline s2 & 1.16 & 0.95 & 4.1 & 4.00 & 4.85 & 4.95 & -0.92 & -1.04 & 0.92 & 1.04 \\
\hline s3 & 1.50 & 1.01 & 4.3 & 4.36 & 6.3 & 5.37 & -0.91 & -1.15 & 0.91 & 1.15 \\
\hline N1 & 0.995 & 0.930 & 3.079 & 3.716 & 3.060 & 3.459 & -0.828 & -0.983 & 0.828 & 0.983 \\
\hline N2 & 1.140 & 1.126 & 3.850 & 4.852 & 4.398 & 5.464 & -0942 & -1.098 & 0.942 & 1.098 \\
\hline N3 & 1.702 & 1.361 & 3.973 & 5.729 & 6.762 & 7.798 & -0.894 & -1.142 & 0.894 & 1.142 \\
\hline
\end{tabular}

S1=pure fodder beet, S2=fodder beet+lentil , S3=alone lentil.

Effect of Preceding crops and nitrogen fertilization on cereal unit:

Data in table(8) show also that the average of cereal unit varied by different of preceding crops and nitrogen fertilizer.The results indicated that the preceding crop lentil gave the highest values of cereal units( 49.6 and 55.35 ) in both seasons, respectively. While the lowest values was observed with fodder beet(45.10 and49.45) in both seasons, respectively.

Table ( 8 ): Cereal units to solid and intercropping of both season.

\begin{tabular}{|c|c|c|c|c|}
\hline $\begin{array}{c}\text { Preceding } \\
\text { crops }\end{array}$ & Cropping system & \multicolumn{2}{|c|}{ Cereal units } & \\
\hline & Solid Maize & First season & Second season & Mean \\
\hline Fodder beet & 33.29 & 37.51 & 35.4 \\
\hline & $\begin{array}{c}\text { Maize+Sunflower+F.berse } \\
\text { em }\end{array}$ & 45.12 & 49.45 & 94.57 \\
\hline $\begin{array}{c}\text { Fodder } \\
\text { beet+lentil }\end{array}$ & $\begin{array}{c}\text { Solid Maize } \\
\text { Maize+Sunflower+F.berse } \\
\text { em }\end{array}$ & 47.47 & 52.41 & 49.94 \\
\hline & $\begin{array}{c}\text { Mean } \\
\text { Lentil }\end{array}$ & & 37.51 & 35.4 \\
\hline & $\begin{array}{c}\text { Solid Maize } \\
\text { em }\end{array}$ & 33.29 & 37.15 & 35.4 \\
\hline & Mean & 49.6 & 55.35 & 52.48 \\
\hline
\end{tabular}

\section{Economic Evalution:}

Gross Return:

The highest total income were(L.E.9086.49 and 9428.01)in the first and second seasons, respectively, when maize was intercropped with sunflower and f.berseem afeter lentil and highest level of nitrogen in both seasons(Table9). 
J. Plant Production, Mansoura Univ., Vol. 5 (7), July, 2014 


\section{REFERENCES}

Abou-Kresha, M.A., El Mihi, M.M., El-Habbak, K., El-Masry, M.A. and Kamel , A.S. (1991). Varietal response of fodder beet intercropped with faba bean to different patterns of intercropping. Egypt. J.Appl.Sci.,(8)225232

Agricultural Statistics(2012):Economic Affairs Sector,Ministry of Agriculture,Egypt,(in Arabic).

Black, C.A., 1965: Methods of soil analysis. Amer., Soc., of Agron. Inc., Madison,Wisconsin, USA.

Brockhaus, V.L.(1962).ABCderLandwirtschaftipartr1, $2^{\text {nd }}$ ed.VEB,BrockhausVer iag, Leipzig,Germany,P:488-489.

De- Wit, C.T. (1960): Intercropping its important an research needs. Part 1. competition and yield advantages. Verslay Langbov WKundige onderzoek No. 66 : 1 - 82 LC .F. willey, R.W., 1979): (C.F. field crop Abst., 32, 1 - 10. )

Fageria, N.K. and Gheyi, H.R. (1999). Efficient crop production Cambia Grande, P Paraiba, Brazil. Univ. of Paraiba.

Fageria, N.K. and Baligar, V.C. (2005). Enhancing nitrogen use efficiency in crop plants. Adv. Agron., (88):97-185.

Fageria, N.K. (2007). Green measuring in crop production. J. Plant Nut., (30):691-719

Fauki, S. and Trenbath, B. R.(1993): processes determining intercrop productivity and yield components crops. Filed crops Res., (34):247271.

Francis, C.A. (1984). Distribution and importance of multiple cropping systems. Macillan Publishing Compony, New York, USA

Gardner, F.B., Peacre, R.B. and Mitchel, R.L. (1985). Physiological of crop plants. lowa state Univ. Press, Ames, lowa, U.S.A.

Gomez, K.A. and A. Gomez. 1984. Statistical Procedures of Agricultural Research. John Wiley \& Sons, New York, 2nd ed., 680p.

Hiebsch,C.K. andR.E. McCollum,1987.Area-x-time equivalation ratio:A method for evaluating the productivity of intercrops Agron.J.,79:15-22.

Khalil, H.E., Nawar, A.I., Abou Elela, Abdel, A.M., Mohammadein, I.E., and El-Sadany, M.E. (2011). Response of maize to $\mathrm{N}$ fertilization following sunflower and winter preceding crops.Alex.J.Agric.Res.,56(2):11-19.

Khalil, H.E., Nawar, A.I., Seif El-Na, F. M and Zahira, M. Attia (1997). Faba bean and fodder beet in monocultures and associations under phosphorus fertilizer application. Adv. Agric. Res., (2):13-23.

Khalil, H.E., Nawar, A.I. and Kanel, A.S. (2004). Response of sunflower to multi seasonal crop sequences under different regimes of NPK. Fertilization. Alex. J. Agric. Res., (49):12-23.

Khalil, H. E. andA. I. Nawar. 2004. Productivity of maize and soybean association patterns after different winter crops. Minufiya J. Agric. Res. 29 (3): 679-693. 
Loomis,RS andCoonor,DJ(1992):Ecology management in Agriculture production processes.Pp.193-233,CambridgeUniv.,New York.USA.Gillchrist,C.A.(1965):Analysis of competition experiments .Biometrics ,21:975-985.

Nawar, A.I. (2004). Nitrogen requirements for maize cultivars after different winter crops. J. Adv. Agric. Res., (9):607-622. (Fac.Agric., Saba Basha , Egypt Piper, C.S., 1950. Soils plants analysis. Intersciences publishers, New York.

Sinclair, T.R. and Horie, T (1989). Leaf nitrogen, photosynthesis and crop radiations use efficiency. A review, Crop Sci., (29): 90-98

Standford, G. 1973. Rational for optimum nitrogen fertilization in corn production. J. Environ. Qual. 2: 156-166.

Standford, G. 1966. Nitrogen requirements of crops for maximum yield, pp. 237-257. In W.H. Mc Vickar (ed.) Agricu. Anhydrous AmmoniaTechnology and Use. Soil Sci.Soci.of America Inc., Madison, Wisconsin

Viets, F. G., Jr. 1965. The plant's need for and use of nitrogen, pp 503-549. In W. V. Bartholomew and F. E. Clark (eds.) Soil Nitrogen. Agron. 10. Amer. Soci. of Agron., Madison, Wisconsin.

Wallach, D. (1995). Empirical Bays optimal fertilizer decision. J. Appl. Stat., (22):507-516

Waller, R.A. and D.B. Duncan. 1969. A bays rule for the symmetric multiple comparison problem. Amer. Stat. Assoc. J., 1485-1504

Willey,R.W. ands.O.Osiru(1972):Studies on mixture of maize and beans(phaseolus vulgaris with particular reference to plants population.J.Sci.Combridge,79.519-

529.(C.F.Moursi.,1983,p.11.) 
تاثير المحاصيل السابقة و التسميد الازوتى على محصول الذرة و دوار الثمس المحملين

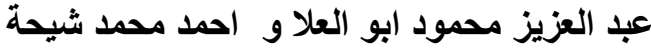
قسم بحوث التكثيف المحصولى- معهد بحوث المثل الحاصيل الحقليةـ مركز البحوث الزراعية_الجيزة

اقيمت تجربتان حقليتان بالمزر عة البحثية بمحطة البحوث الزر اعيدة بالجميزة بمحافظة الغريبة خلال

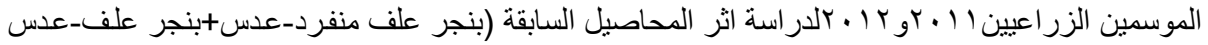

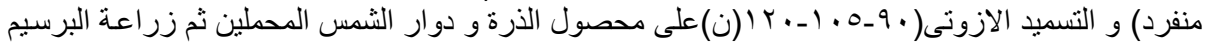

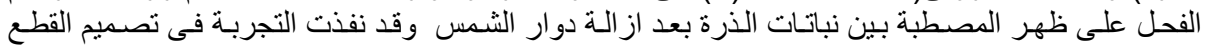
المنشقة مرة واحدة فى ثلاث مكررات.

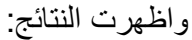

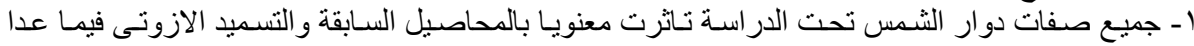

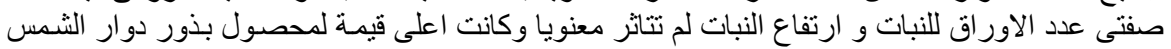
ع .

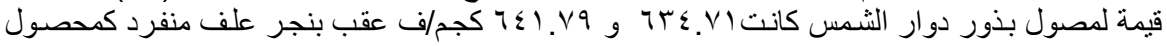

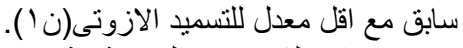

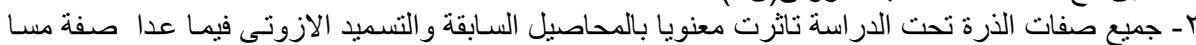

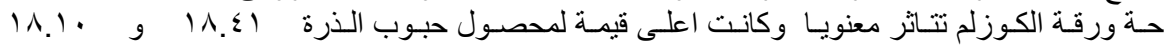

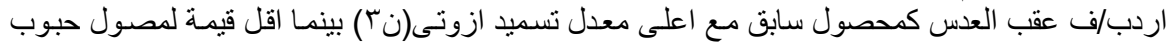

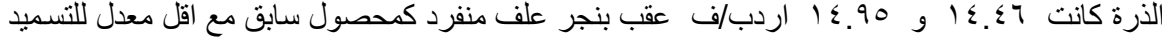

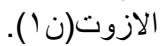
rـ لم يناثر التفاعل بين المحاصيل السابقة والتسميد الازوتى معنويا لكل صفات دوار الثمس و الذرة تحت

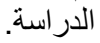

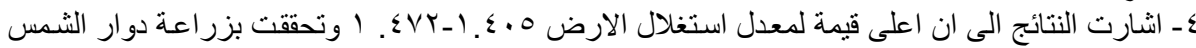

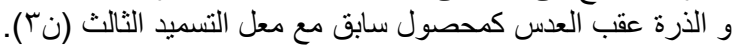

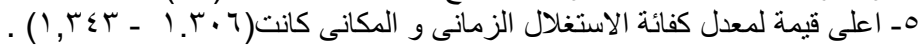

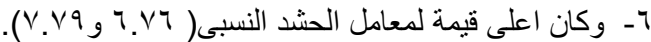

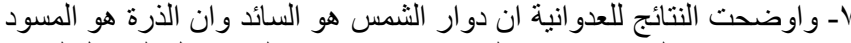

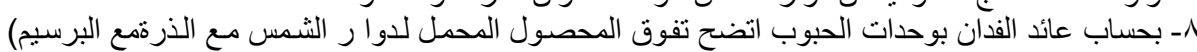

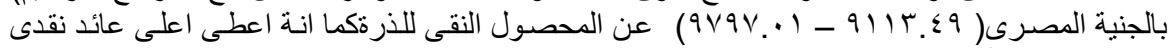

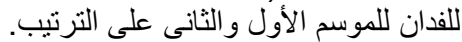
التوصية:اوضحت الدر اسة طبقا لظروف التى التجربة ان افضل نتيجة كانت بالزر اعة عقب عدس كمصصول سابق

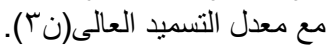


Table 9:Total income of sunflower and maize advantages of preceding crops in 2011/2012 seasons.

\begin{tabular}{|c|c|c|c|c|c|c|c|c|c|c|}
\hline & \multicolumn{2}{|c|}{ Solid sunflower(kg) } & \multirow{2}{*}{\begin{tabular}{|c|}
$\begin{array}{c}\text { Solid } \\
\text { maize(ardab) }\end{array}$ \\
Grain yield \\
\end{tabular}} & \multicolumn{2}{|c|}{ SunflowerS1 } & \multirow{2}{*}{$\begin{array}{c}\begin{array}{c}\text { Maize } \\
\text { (ardab) }\end{array} \\
\begin{array}{c}\text { Grain } \\
\text { yield }\end{array}\end{array}$} & SunflowerS2 & \multirow{2}{*}{$\begin{array}{c}\text { Maize } \\
\text { (ardab) } \\
\text { Grain } \\
\text { yield } \\
\end{array}$} & $\begin{array}{c}\text { Sunflower } \\
\text { S3 }\end{array}$ & \multirow{2}{*}{\begin{tabular}{|c|}
$\begin{array}{c}\text { Maize } \\
\text { (ardab) }\end{array}$ \\
Grain yield \\
\end{tabular}} \\
\hline & $\begin{array}{c}\text { Seed yield } \\
(\mathrm{kg})\end{array}$ & & & $\begin{array}{c}\text { Seed yield } \\
(\mathrm{kg})\end{array}$ & & & $\begin{array}{c}\text { Seed yield } \\
(\mathrm{kg})\end{array}$ & & $\begin{array}{c}\text { Seed } \\
\text { yield(kg) }\end{array}$ & \\
\hline \multicolumn{11}{|l|}{2011} \\
\hline Yield & 1015.17 & & 22.35 & 634.71 & & 14.46 & 659.52 & 15.78 & 683.71 & 16.96 \\
\hline Actual yieldL.E. & & & & 2158.01 & & 4381.38 & 2242.37 & 4781.34 & 2324.61 & 5138.88 \\
\hline Total incomeL.E. & 3451.58 & \multicolumn{2}{|c|}{6772.05} & & & 3539.39 & & 7023.71 & & 7463.49 \\
\hline \multicolumn{11}{|l|}{2012} \\
\hline Yield & 1065.67 & & 24.65 & 693.81 & & 15.71 & 733.91 & 17.25 & 799.64 & 18.41 \\
\hline Actual yield L.E. & & & & 2358.95 & & 4760.13 & 2495.29 & 5226.75 & 2718.78 & 5578.23 \\
\hline Total incomeL.E. & 3623.28 & & 468.95 & & & 19.08 & & 7722.04 & & 8297.01 \\
\hline
\end{tabular}

$(7463.49+1650=9113.49$ first season and 8297.01+1500=9797.01 second season for intercropped maize+sunflower+f.berseem)

Gross return from each treatment was calculated in Egyptian pounds(LE)at prices of LE3415/ $t$ for (seed) for sunflower ,L.E.150/t for f.berseem and LE303/ ardab for maize.(Agricultural Statisties(2012), Economic Affairs Sector) 